\title{
The Confused U.S. Framework for Foreign-Bank Insolvency: An Open Research Agenda
}

STEVEN L. SCHWARCZ*

Duke University School of Law

\section{INTRODUCTION}

Many of the world's banks have operations, if not branches or agencies, in the United States. ${ }^{1}$ When these banks fail, their U.S. operations and assets are subject to a confused, and confusing, patchwork of insolvency laws, both federal and state. This essay examines that legal patchwork, asking whether it is desirable, much less efficient, ${ }^{2}$ for a nation to have an inconsistent foreignbank insolvency regime. The essay does not attempt to provide final answers but, instead, focuses on identifying the threshold conceptual issues that must be resolved before attempting to provide answers.

Some of these threshold issues, it will be seen, are intrinsic to any patchwork legal scheme. To what extent, for example, is inconsistency offset by potential for experimentation? Other issues, however, may be unique to foreign bank insolvency. For example, with a multitude of separately-governing laws, any

\footnotetext{
* Stanley A. Star Professor of Law \& Business, Duke University School of Law; Founding Director, Duke Global Capital Markets Center. E-mail: schwarcz@law.duke.edu. The author thanks Lissa Broome, John Douglas, Andrew Karp, Joseph Sommer, Peter Swire, and two unidentified reviewers for helpful comments; and Lorri M. Clark, Luciona Johnson, and Howard A. Wachtel for research assistance.

1 As of September 2004, U.S. offices of foreign banks held over $\$ 1.5$ trillion of assets and approximately $\$ 786$ billion of deposits. (Federal Reserve Board, 2004). This represents $17.8 \%$ of assets, and $15.3 \%$ of deposits, held by all banks in the United States at that time.

2 In the context of a foreign-bank insolvency regime, desirability can be different from efficiency in terms of distributional consequences and national policy considerations.
} 
given law will govern relatively few foreign-bank insolvencies. Does that absence of a critical mass undermine incentives for law reform?

Resolution of these and other threshold issues could have practical as well as theoretical importance. With the increasing interconnectedness of the international banking system, a foreign bank's insolvency could trigger banking failures in the United States and globally. ${ }^{3}$ This potential for systemic failure ${ }^{4}$ underscores the growing importance of striving for informed foreign-bank insolvency laws.

My essay begins by describing the foreign-bank insolvency regime in the United States, as it currently exists.

\section{THE EXISTING FOREIGN-BANK INSOLVENCY REGIME}

In the United States, foreign bank insolvency has its own legal framework, quite different from that of corporate bankruptcy and domestic bank insolvency. ${ }^{5}$ Corporate bankruptcy is governed by the federal Bankruptcy Code (11 U.S.C. IS 101 et seq.), which provides a comprehensive and internally consistent framework for reorganization and, where applicable, liquidation of non-bank debtors. ${ }^{6}$ Domestic bank insolvency is somewhat more complicated,

\footnotetext{
3 Tarbert (2000) observes that "[T] he danger of systemic risk [is] global and no longer within the confines of any national border. Thus, even if capital standards were imposed on American banks, the insolvency of a major Japanese or European bank could cause U.S. banks to fail as well." And, citing the Shadow Financial Regulatory Committee (1999), "The danger of systemic risk is global and no longer within the confines of any national border. Because international banks were active in multiple countries and were linked together through common clearing and settlement systems...the failure of one or more of these institutions in one country could adversely affect the financial welfare of other institutions in other countries"). See also Financial Centres (1989) noting that "[T]he banking system is international; the failure of a bank in Frankfurt could affect the banking system around the world."

${ }^{4}$ As indicated in note 3, this essay focuses on systemic failure of banks linked through common clearing and settlement systems, where "failure of a large foreign bank with placements from, or settlement obligations to, other large banks could cause an international chain reaction of bank failures." Scott (1995) observes that, for this reason, "[c]ountries are concerned with the failure of foreign banks". A related systemic failure is the "bank run" by depositors. See, e.g., Swire (1992:494).

${ }^{5}$ See Baxter et al. (2004:71) observing that some nations, like the United Kingdom, apply ordinary or slightly modified insolvency law principles to banks; others, like the United States and Japan, have "completely different insolvency regimes for banks"; but most nations have mixed regimes.

${ }^{6} 11$ U.S.C. Chapter 11 governs reorganization; 11 U.S.C. Chapter 7 governs liquidation.
}

Review of Law \& Economics, ( 2005 by bepress 
being explicitly excluded from the Bankruptcy $\operatorname{Code}^{7}$ and governed instead by a mixture of federal and state bank insolvency laws. ${ }^{8}$ Foreign bank insolvency, however, is far more complicated still.

As the discussion below illustrates, foreign-bank insolvency sometimes is governed by certain provisions of the Bankruptcy Code, sometimes by other provisions of that Code, and sometimes by a separate mélange of federal and state bank insolvency laws (Patrikis, 1999:286). In the first instance, the governing law turns on a factor that is independent of insolvency: whether or not the foreign bank has branches or agencies in the United States. ${ }^{9}$

Where an Insolvent Foreign Bank Lacks Branches or Agencies in the U.S.: If the insolvent foreign bank has assets, but no branches or agencies, in the United States ${ }^{10}$ provisions of the Bankruptcy Code would apply to liquidation and distribution of those assets. However, which particular provisions govern is somewhat ad hoc (Mattingly et al., 1999:259).

Most notably, a bankruptcy judge has discretion-in the interest of furthering the efficiency of foreign insolvency cases involving assets located in the United States - to make those assets the subject of a $\int 304$ ancillary proceeding under the Bankruptcy Code, if so requested by the foreign bank's home-country liquidator in a "foreign [liquidation or similar] proceeding." 11 In these

\footnotetext{
7 The Bankruptcy Code excludes domestic banks from being a "debtor" thereunder. 11 U.S.C. $\S 109$ (b) (2).

${ }^{8}$ Because of this patchwork, some of my concerns regarding the foreign bank insolvency legal framework may have applicability to the domestic bank insolvency legal framework. This essay, however, is limited to foreign bank insolvency.

9 Although the distinction between branches and agencies is irrelevant for purposes of this essay, a branch of a foreign bank is an office that can book assets and sometimes can incur liabilities such as deposit liabilities to certain customers (though it is rare for these deposit liabilities, where they exist, to be FDIC insured). 12 U.S.C. \$ 3101(3). An agency of a foreign bank is an office that is licensed in the United States to book assets and liabilities (though it cannot book deposit liabilities to U.S. residents) for that bank-e.g., making loans and extending banking commitments to U.S. borrowers-but typically is not regarded as a separate legal entity. 12 U.S.C. \3101(1). See also e-mail from John Douglas, Bank Regulatory Partner, Alston \& Bird, and former General Counsel, Federal Deposit Insurance Company, to the author (November 29, 2004).

10 This may occur, for example, where the foreign bank only has a representative office in the United States.

11 11 U.S.C. \ 304. The term "foreign proceeding" is broadly construed, and includes any liquidation or similar proceeding administered by the foreign bank's home regulatory agency. (American Jurisprudence 2d: 9A-Bankruptcy $\$ 851). See also 11 U.S.C. $\ 101(23)$ stating that the foreign proceeding merely need be a "proceeding, whether judicial or administrative and whether or not under bankrupty law, ... for the purpose of liquidating an estate, adjusting debts by composition, extension, or discharge, or effecting a reorganization" (emphasis added). If and when it is adopted by the United States, the UNCITRAL Model Law on Cross-Border Insolvency would replace $\ 304$
} 
proceedings, the U.S. bankruptcy court has discretionary power to impose a stay on creditors and turn over the foreign bank's U.S. assets to the home country liquidator for distribution under the home country's law (11 U.S.C. \$ 304(b))..$^{12}$ Although the bankruptcy court should regard comity as an important factor in making a turnover decision (Mattingly et al., 1999:270-71), in practice bankruptcy courts are reluctant to turn over assets to a home country (i.e., foreign) liquidator unless "U.S. creditors [have] the ability to pursue their claims in the foreign proceedings and ... there [is] parity between the laws of both the foreign jurisdiction and the United States so as to grant the same level of protection to U.S. creditors in the foreign proceeding (Mattingly et al., 1999:271; 11 U.S.C. \$S 304(c)(1)-(c)(4))."

To date, the "overwhelming majority" of foreign bank asset liquidationsagain, where the foreign bank lacks branches and agencies in the United States-have been conducted pursuant to $\int 304$ ancillary proceedings (Mattingly et al., 1999:273). ${ }^{13}$ Where, however, bankruptcy judges refuse a request by the foreign bank's home-country liquidator for a $\ 304$ ancillary proceeding, liquidation of U.S. assets of a foreign bank lacking branches and agencies in the United States would likely proceed via a Chapter 7 case under the Bankruptcy Code (Mattingly et al., 1999:259). Chapter 7 can apply because the foreign bank, lacking branches and agencies, arguably is not engaged in the banking business in the United States, ${ }^{14}$ and thus would not be excluded from being a "debtor" under $\int 109$ of the Bankruptcy Code. ${ }^{15}$

ancillary proceedings. That should not create dramatic changes because the Model Law is largely procedural and is based on the principles of $\ 304$. Furthermore, like $\ 304$, the UNCITRAL Model Law excludes banks from its scope (Patrikis, 1999:286).

12 Accord, Mattingly et al. (1999:259-60). If a stay is imposed, creditors would be prevented from seizing, attaching, garnishing, or otherwise executing against assets located in the U.S.

13 Although the case law is mixed, there is good authority that a $\int 304$ ancillary proceeding sought by an insolvent foreign bank without branches or agencies in the United States would be permitted. See In re Goerg, 844 F.2d 1562 (11 th Cir. 1988), cert. denied, 488 U.S. 1034 (1989); In re Agency for Deposit Ins., Rehab., Bankruptcy \& Liquidation of Banks, 310 B.R. 793 (U.S.D.C., S.D.N.Y., 2004); Samet (2004:261-62). One U.S. court recently even permitted a $\ 304$ ancillary proceeding sought by a foreign bank with a branch in the United States. See Agency for Deposit Insurance, Rehabilitation, Bankrupty and Liquidation of Banks v. Superintendent of Banks, 310 B.R. 793 (U.S.D.C., S.D.N.Y., 2004).

14 That business being defined by the ability to take deposits. (American Jurisprudence $2 d: 9 \int 40$. Also Collier on Bankrupty ( $(2-109: 109.03,09.03$ n. 26) arguing that the reason Chapter 7 of the Bankruptcy Code applies is that otherwise there would be no law governing "liquidation of any of the [foreign bank's] assets in the United States."

1511 U.S.C. S 109(b)(3) (excluding only foreign banks "engaged in such business in the United States").

Review of Law \& Economics, ( 2005 by bepress 
Where an Insolvent Foreign Bank Has Branches or Agencies in the U.S.: Where the insolvent foreign bank has at least one branch or agency in the United Statesto that extent indicating a greater U.S. presence ${ }^{16}$ - Chapter 7 of the Bankruptcy Code would not apply because foreign banks engaged in business in the United States are excluded from being a "debtor" thereunder (11 U.S.C. \$ 109(b)(3) \& (d); Mattingly et al., 1999:259, 273). Although there is a recent case to the contrary, $\int 304$ ancillary proceedings also would not appear to apply. ${ }^{17}$ The insolvency then would be governed by federal banking insolvency lawwhich is completely different from the federal Bankruptcy Code ${ }^{18}$-if the branch/agency is federally licensed or chartered (typically through the Office of Comptroller of the Currency, or "OCC") (Mattingly et al., 1999:262; 12 C.F.R. $\S \S 28.10-.26)$, or by state banking insolvency law if the branch/agency is state licensed or chartered (Mattingly et al., 1999:262). Because foreign banks obtaining licenses or charters do not expect their branches and agencies to fail, decisions where to originally license or charter a foreign bank's branches and agencies (federally or under state law) typically are made with little regard to insolvency law consequences. ${ }^{19}$

16 A greater U.S. presence, of course, represents a more troublesome scenario from the standpoint of the insolvent foreign bank's potential systemic impact on the U.S. banking system.

17 Although insolvent foreign banks with branches or agencies in the United States are excluded from being a debtor under the Bankruptcy Code, such banks theoretically might also be eligible for a \304 ancillary proceeding. In practice, though, courts are reluctant to utilize $\$ 304$ where a foreign bank's U.S. branch or agency is subject to explicit federal or state bank insolvency law. A $\int 304$ ancillary proceeding then would not only be unnecessary to "further efficiency," but would represent a duplicative cost. But see Agency for Deposit Insurance, Rehabilitation, Bankrupty and Liquidation of Banks v. Superintendent of Banks, 310 B.R. 793 (U.S.D.C., S.D.N.Y., 2004) (reversing a bankruptcy court ruling that $\ 304$ ancillary proceedings would be unavailable for New York State-licensed branches of failed banks Jugobanka A.D., Beograde, and Beogradska Banka A.D.); Agency for Deposit Insurance, Rehabilitation, Bankruptcy and Liquidation of Banks v. Superintendent of Banks, 2004 WL 1812823 (U.S.D.C., S.D.N.Y., 2004) (denying motion by New York Superintendent of Banks to reconsider court's order resulting from earlier decision or, alternatively, to certify that order for immediate appeal). U.S. federal and state bank regulators-concerned that failed foreign banks could use these decisions to repatriate their assets in the United States and disturb insolvency regimes that favor creditors of the U.S. branches and agencies-are pressing for reversal of these decisions, which they say are contrary to other U.S. precedents, and also are urging Congress to legislatively change $\ 304$ to nullify the decisions' impact. See Blackwell (2004).

${ }^{18}$ See notes 19-26 and accompanying text (describing federal banking insolvency law).

19 See, e.g., John Douglas, Bank Regulatory Partner, Alston \& Bird, and former General Counsel, U.S. Federal Deposit Insurance Corporation (e-mail to the author dated Feb. 9, 2005) observing that "I think you are right about [foreign banks obtaining licenses or charters] not taking into account insolvency. They are more concerned with the business they can conduct (e.g., does it need to be a branch $\mathrm{v}$ an agency), the location of the office, and their regulator (FRB/State v OCC). There is a bit of lemming instinct in the foreign banks as well-if $\mathrm{X}$ bank is 
Under federal banking insolvency law, the principal statute governing liquidation of U.S.-licensed branches and agencies of foreign banks is the International Banking Act of 1978, as amended (Mattingly et al., 1999:263). Under this Act (12 U.S.C. $\iint 3101$ et seq.), ${ }^{20}$ the OCC or other regulator may appoint a receiver to liquidate the branch or agency under certain circumstances (though in practice there appears to be relatively little precedent where the OCC has appointed a receiver for a foreign bank's branch or agency (Mattingly et al., 1999:263, n.12; 12 U.S.C. \ 3102(j).) Notwithstanding a receiver's appointment, the OCC controls proofs of claim and payments to depositors and other creditors of the foreign bank in the United States (Mattingly et al., 1999:263). And, even where a receiver is appointed, its right to impose a stay on creditors "is either attenuated or non-existent (Patrikis, 1999:287)."21

Because the International Banking Act authorizes the receiver to "take possession of all the property and assets of such foreign bank in the United States," 22 and not merely to take possession of the assets of the foreign bank's branches and agencies, the receiver appears to have broad power to liquidate any assets of the foreign bank in the U.S., even if such assets are not owned by the foreign bank's branch or agency (Mattingly et al., 1999:263, 270; Patrikis, 1999:287). To this extent, the foreign bank and its U.S. branches and agencies are treated as a single entity.

a state/FRB bank, I should be as well."); and an e-mail from Jeffrey P. Taft, Bank Regulatory Partner, Mayer, Brown, Rowe \& Maw LLP, to the author (Feb. 10, 2005) observing that "I believe that the reason you cite (i.e., they [the foreign banks] do not expect to become insolvent) is correct. In the US, most business people do not immediately move their residence to states with large homestead exemptions or other similar carve outs from the bankruptcy laws when they are starting a business. It is only at a later date when the prospect of bankruptcy is less remote that they decide to purchase a large home in Florida and take up residence in Florida [to take advantage of that state's large homestead exemption]. I have helped a number of clients over the years set up state and national credit card banks in various states. In determining where to locate the bank, we consider a number of business factors (permissible rates and fees imposed on cardholders, taxes, education level of the labor force, cost of operating a business, litigation climate) and regulatory issues such as supervision and examination. ... [B] ased upon my experience, the initial focus of the business people relates to profitability and costs so even if there was a difference in insolvency regimes, it would not merit any consideration.."

${ }^{20}$ Under the Act, a single federal liquidation scheme will apply to all of a foreign bank's U.S. offices where any branch or agency of the foreign bank is federally licensed. (Mattingly et al. 1999:263). See also 68 Fed. Reg. 70691 (Dec. 19, 2003) (codified at 12 C.F.R. pts. 5 \& 28).

${ }^{21}$ For example, 12 U.S.C. $\iint 1821$ (d)(2) \& (d)(12) authorize the FDIC to request only a shortterm stay of judicial action.

${ }^{22}$ International Banking Act $\int 4(j)(1)$.

Review of Law \& Economics, ( 2005 by bepress 


\section{U.S. Framework for Foreign-Bank Insolvency / 87}

In contrast, however, the U.S. liquidation itself would be separate from any home-country liquidation of the foreign bank (Mattingly et al., 1999:270), and U.S. law only recognizes claims - whether domestic or foreign ${ }^{23}$ - against the foreign bank's U.S. offices (Mattingly et al., 1999:270; Patrikis, 1999:287). To this extent, the foreign bank and its U.S. branches and agencies are treated as separate entities. The result is that U.S. law maximizes the "estate" in the United States of foreign bank assets available for payment of claims, but minimizes the universe of claims that may be asserted against that estate. ${ }^{24}$

Federal banking insolvency law also contemplates the possibility of reorganization rather than liquidation. If the Federal Deposit Insurance Company (FDIC) insures the foreign bank branch, it will manage the branch's reorganization (Mattingly et al., 267). The FDIC may obtain a temporary stay on judicial debt collection by creditors, but the stay does not prevent secured creditors from exercising self-help remedies (12 U.S.C. $\int 1821$ (d)(12)). ${ }^{25}$

Most U.S. branches and agencies of foreign banks are not FDIC-insured, ${ }^{26}$ however, and federal law then looks to the insolvency reorganization scheme of the chartering/licensing authority--typically, as mentioned, such authority being the OCC. Unfortunately, the law here is "not well developed" (Mattingly et al., 1999:268).

Where the branch/agency is state, not federally, licensed or chartered, state banking insolvency law applies. ${ }^{27}$ With the implementation in the U.S. of interstate banking, many states have updated their bank insolvency laws, and "the laws of the states with a large foreign bank presence are now quite similar" (Mattingly et al., 1999:272).28

\footnotetext{
${ }^{23}$ Federal bank regulatory agencies are prohibited from paying claims to foreign depositors of insolvent FDIC-insured banks (Malloy, 1998).

${ }^{24}$ Patrikis (1999:287) refers to this as a "'territorial' insolvency approach." One might contrast this with a "universalistic" approach in which worldwide assets are liquidated for distribution to worldwide creditors. See Mattingly et al. (1999:270).

25 Accord, Mattingly et al. (1999:268) and Comptroller of the Currency Interpretative Letter No. 748, 1996 OCC Ltr. LEXIS 117 (Sept. 13, 1996), concluding that "the direction to the receiver in section 4(j)(1) of the [International Banking Act] to 'take possession' of all the property and assets of the foreign bank in the U.S. does not supersede the applicable law of secured transactions."

${ }^{26}$ See note 9 .

27 But compare for example note 17 and accompanying text (discussing a recent highlycriticized decision holding that $\ 304$ ancillary relief may be available to the foreign branch/agency). Where the foreign bank has any federally-licensed branch or agency, the federal bank insolvency framework would preempt the state framework-even for state-licensed or chartered branches or agencies of that foreign bank. See also note 20.

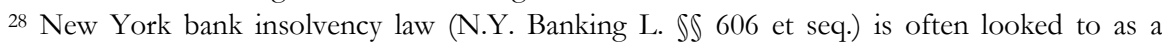
model for these laws (Baxter et al., 2004).
} 
In general, as under federal bank insolvency law (Mattingly, 1999; Malloy, 1999), a receiver under state bank insolvency law ${ }^{29}$ appears to have broad power to liquidate U.S. domestic assets of the foreign bank, even those not owned by the foreign bank's branch or agency (Risk Institute, 2004). Similarly, claims against the foreign bank's U.S. domestic offices will have priority in those liquidated assets superior to claims against the foreign bank (Risk Institute, 2004). State bank insolvency law therefore favors territoriality, and "is no basis for a cooperative international [insolvency] regime" (Baxter et al., 2004:76).

Summary: This polyglot of regulation can be summarized as follows. If the insolvent foreign bank has assets, but no branches or agencies, in the United States, a bankruptcy judge has discretion to make those assets the subject of a $\int$ 304 ancillary proceeding. In such a proceeding, the judge has further discretion to impose a stay on creditors and turn over the foreign bank's U.S. assets to the home country liquidator for distribution under the home country's law. Absent such a proceeding, however, the insolvent foreign bank's U.S. estate would be resolved under domestic corporate bankruptcy-liquidation law..$^{30}$

Where, however, the insolvent foreign bank has at least one branch or agency in the United States, its insolvency would be governed by federal banking insolvency law if the branch/agency is federally licensed or chartered, and by state banking insolvency law if the branch/agency is state licensed or chartered. Decisions where to license or charter a foreign bank's branches and agencies are made, however, with little regard for insolvency law consequences.

Even if those decisions were made with full regard for insolvency law consequences, federal banking insolvency law is not well developed. It does not, for example, impose a credible stay on creditors. It also inconsistently treats the insolvent foreign bank and its U.S. branches and agencies as a single entity for certain purposes, but not for others. Furthermore, in direct contrast to $\int 304$ ancillary proceedings - which contemplate the possibility, where appropriate, of turning assets located in the United States over to a foreign

\footnotetext{
${ }^{29}$ In general, the receiver or conservator would be the applicable state bank regulatory agency; although in the case of an FDIC-insured state-licensed branch of a foreign bank, that state agency could request the FDIC to act, and the FDIC may so act, as receiver or conservator (12 U.S.C. $\left.\int 1821(\mathrm{c})\right)$. Thus, in the case of insolvency of a New York State-licensed branch of a foreign bank, the Superintendent of the New York State Banking Department would act as receiver or conservator unless the FDIC is asked, and agrees, to so act (N.Y. Banking L. $\mathbb{S}$ 606(4)(a)).

${ }^{30}$ Chapter 7 of the federal Bankruptcy Code.
}

Review of Law \& Economics, ( 2005 by bepress 
representative-federal banking insolvency law is effectively xenophobic, recognizing only claims against the foreign bank's U.S. offices. ${ }^{31}$

To complicate matters, state bank insolvency law is materially different than federal banking insolvency law and also varies state to state--though the good news is that the laws of states with a large foreign bank presence are now quite similar. $^{32}$ State bank insolvency law appears to favor territoriality over universality.

The foregoing patchwork framework is further complicated by the fact that, in the unusual case that an insolvent foreign bank has a branch or agency licensed or chartered in one state and assets in another state in which it has no branch or agency, it is unclear what insolvency law would govern the liquidation of assets in that other state (Mattingly et al., 1999:274). ${ }^{33}$

I next analyze this framework, attempting to identify the issues that are fundamental to determining its desirability and efficiency.

\section{ANALYSIS}

The fact that a legal framework is complicated, and even inconsistent, is not necessarily troublesome. Indeed, allowing possible variation in an otherwise uniform legal regime offers the potential for experimentation. ${ }^{34}$ I believe, however, that the complications and inconsistencies of foreign-bank insolvency law in the United States appear, on balance, to create a poor legal framework.

On a conceptual level, the law's patchwork framework reflects fundamental inconsistencies in legal philosophy. Section 304 ancillary proceedings, for example, strive for "universality," in which the domestic insolvency regime

${ }^{31}$ Query the extent to which this limited claims recognition might discourage U.S. investment by foreign banking organizations.

32 Moreover, contrary to existing authority, a court recently recognized a $\ 304$ ancillary proceeding notwithstanding the application of state bank insolvency law. See Agency for Deposit Insurance, Rehabilitation, Bankruptcy and Liquidation of Banks v. Superintendent of Banks, 310 B.R. 793 (U.S.D.C., S.D.N.Y., 2004).

33 If, however, the foreign bank has a federally-licensed branch or agency, the federal bank insolvency framework would apply. See note 20.

34 In a commercial-law context, for example, at the time the Uniform Commercial Code ("UCC") first was promulgated in the United States, security interests in bank deposit accounts were excluded from its coverage due to concerns in the banking community. California, however, enacted a non-uniform provision facilitating security interests in deposit accounts. Decades later, when the UCC was being amended, the author observed that the successful California experience with those security interests was instrumental in persuading drafters of the amendments and the banking community that security interests in deposit accounts now should be covered. 
takes into account foreign insolvency regimes and attempts to harmonize the domestic and foreign regimes_-such as by permitting a U.S. judge to consider whether to turn over the foreign bank's U.S. assets to the foreign liquidator for distribution. ${ }^{35}$ Federal banking insolvency law, in contrast, is clearly focused on "territoriality," 36 permitting only creditors with U.S. claims to grab ${ }^{37}$ the foreign bank's assets. ${ }^{38}$

I am not claiming the framework must be philosophically consistent. For example, at least some of the inconsistency in how the framework presently treats, on the one hand, insolvency of foreign-bank branches or agencies and, on the other hand, assets of insolvent foreign banks without branches or agencies may have implicit rationale. ${ }^{39} \mathrm{I}$ am claiming only that these philosophical inconsistencies should be carefully thought through.

On a practical level, the patchwork framework is so complex that it obscures what should be the fundamental normative goal for a foreign-bank insolvency regime: to ensure that such insolvency does not systemically undermine the domestic or foreign banking systems. ${ }^{40}$ In a world where banks routinely engage in significant portions of their activities internationally, the framework-other than the limited situations in which $\int 304$ ancillary proceedings might apply-is insensitive to the possibility that a foreign bank insolvency in the United States could trigger a banking failure in the foreign nation. Such a failure might be triggered, for example, because federal banking insolvency law compels distribution of the insolvent bank's assets to creditors with U.S. claims, without

\footnotetext{
35 See note 12 and accompanying text.

${ }^{36}$ For a non-bank overview of universality and territoriality in international bankruptcy law, see Bebchuk \& Guzman (1999).

37 The philosophy of territoriality is indeed often described as a "grab race," enabling creditors in the jurisdiction with the debtor's assets to seize those assets first to the exclusion of foreign creditors.

38 See notes 22-24 and accompanying text.

39 The difference in treatment may reflect, to some extent, the possibility that U.S. branches and agencies of foreign banks could have many more U.S. creditors, whose interests might not be fully respected by home-country liquidators. Even that rationale, however, may be insufficient because it does not address the fundamental normative goal for a foreign-bank insolvency regime: protecting against systemic risk. See note 40 and accompanying text.

40 Compare for example Swire (1992:474) arguing that there are three explanations of modern bank insolvency law; of those explanations, only the first- "the systemic effect of bank runs"appears to be applicable to foreign bank-insolvency law). Also compare e-mail from Joseph Sommer, Counsel, Federal Reserve Bank of New York, to the author (Dec. 2, 2004) observing that the patchwork framework itself may be driven by a "lack of articulated policies. People have been flying by the seat of their pants for way too long. It is good that you are trying to force people to articulate their policy concerns, and tie them to legal rules."
}

Review of Law \& Economics, ( 92005 by bepress 
consideration of whether any of those assets should be turned over to the foreign jurisdiction to enable the foreign bank to reorganize.

Another practical concern is that the multitude of foreign-bank insolvency laws, each governing in a narrow jurisdictional niche, makes it likely that any given law will govern relatively few foreign-bank insolvencies. As a result, lawmakers and regulators may have minimal incentive to spend political capital improving any of these laws. Moreover, judicial decisions, already few in number, will develop in isolated contexts. ${ }^{41}$ That could help explain why the existing legal framework, which apparently originated piecemeal, has remained such a mess.

Yet another practical concern is that the patchwork framework may generate unnecessary transaction costs. Such costs arise, for example, because attorneys and other experts must learn and apply the hodgepodge of laws. ${ }^{42}$ Furthermore, where foreign banks engage in financing in the United States, transaction costs can multiply. A colleague at the August 2004 meeting of the American Bar Association's Banking Law Section told me, for example, that when a state-chartered foreign bank recently engaged in a securitization transaction, his firm had to examine the foreign-bank insolvency laws in each of the five states where the bank's branches were located, and also had to retain banking-law counsel in each such state. ${ }^{43}$

These concerns only scratch the surface. They do not, for example, take into account that the patchwork framework undermines expectations: because of its complications, most creditors simply will not have the expertise to predict how their pre-insolvency rights and remedies will survive an insolvency proceeding. ${ }^{44}$ Additionally, although state laws govern insolvency of statechartered foreign bank branches or agencies, these laws may lack national and international perspective. And any such laws having that perspective could be

${ }^{41}$ E-mail from Joseph Sommer, Counsel, Federal Reserve Bank of New York, to the author (Dec. 2, 2004) observing also that "less than one case a year makes it into US courts."

42 Compare Schwarcz (1995:940) observing that, prior to enactment of the Uniform Commercial Code in the United States, "commercial law was full of contradictions and gaps making commercial practice uncertain, time-consuming, and expensive."

${ }^{43}$ In accord with this, Joseph Sommer, Counsel, Federal Reserve Bank of New York, in an email to the author (Dec. 2, 2004) states that this ex ante transaction-costs argument is especially compelling; another e-mail to the author from Andrew T. Karp, Bank Regulatory Counsel, Mayer, Brown, Rowe \& Maw LLP (Dec. 23, 2004) who observes that this type of financing for a foreign bank " $[\mathrm{a}] \mathrm{dds}$ a lot of cost and uncertainty."

44 Compare for example Baird (1998) arguing that free-market scholars believe that "[s]ubstantive rules implemented exclusively in bankruptcy are suspect because of the effects they may have on investment beforehand. ... Inconsistency may do more harm than good." 
changed at any time by state legislatures to advance considerations of stateterritoriality over national and international-universality.

\section{CONCLUDING OBSERVATIONS}

I originally asked whether it is desirable, much less efficient, for a nation to have an inconsistent foreign-bank insolvency regime. This essay demonstrates that the U.S. patchwork regime governing foreign-bank insolvency appears neither desirable nor efficient. The essay does not, however, conclusively prove such undesirability or inefficiency.

Any such proof would have to grapple with, and rigorously resolve, at least two fundamental issues. First, how well does the patchwork framework protect against systemic risk to the U.S. and international banking systems? Although protecting against systemic risk is the fundamental normative goal for a foreign-bank insolvency regime, the existing framework is so complex that it obscures that goal. ${ }^{45}$ Second, could a different legal framework be practical and better protect against systemic risk? In that context, this essay focuses on general systemic risk to the U.S. and international banking systems. A comprehensive inquiry, however, also should balance protecting the U.S. banking system per se against the need to avoid inadvertently harming foreign banking systems, which in turn could act as a feedback loop and threaten the interconnected U.S. banking system. ${ }^{46}$

In resolving these issues, the proof would have to address the following related issues. What are the justifications, if any, for the existing framework's distinctions, and how important are those justifications?47 To what extent would more coherent legal frameworks minimize unnecessary transaction costs? What consequences flow from the fact that the patchwork framework reflects fundamental, though random, inconsistencies in legal philosophy; ${ }^{48}$ and, in that context, should a foreign bank insolvency regime favor universality over territoriality?49 Does the patchwork framework minimize incentives for

\footnotetext{
45 See note 40 and accompanying text.

46 See notes 3-4 and accompanying text discussing systemic risk. Compare this with Degryse and Nguyen (2004) examining the contagion risk generated by foreign banks.

${ }^{47}$ In this context, one should examine, among many other things, the extent to which state bank-insolvency laws lack national and international perspectives, and the justifications for lacking those perspectives.

48 See note 39 and accompanying text.

${ }^{49}$ For an excellent overview of the comparison between universality and territoriality in the context of international bank insolvency generally, see Baxter et al.. (2004) concluding that although conventional wisdom favors universality for non-bank insolvency law, territoriality may
}

Review of Law \& Economics, ( 2005 by bepress 


\section{U.S. Framework for Foreign-Bank Insolvency / 93}

continuing law reform? ${ }^{50}$ Does the patchwork framework undermine creditor expectations and, if so, so what? In this context, one possible way to protect creditor expectations and enhance law reform is to consider allowing or perhaps even requiring foreign banks to choose the applicable insolvency law when they establish branches or agencies. ${ }^{51}$ This could foster development of an expert jurisdiction, such as Delaware in the corporate area, leading to welldeveloped judicial precedents (and thus increased certainty and reduced transaction costs) and motivating - at least through bank lobbying ${ }^{52}$ continuing reform. ${ }^{33}$ Of course, any proposal for allowing or requiring foreign banks to choose applicable insolvency law must take into account the resulting cost of permitting inconsistency as to the rule applied in each case.

Additionally, an important related issue is whether the framework's emphasis on liquidation-rules best protects against systemic risk, or whether there should be more emphasis on reorganization. In this context, it should be recognized that federal banking insolvency law sometimes contemplates the possibility of reorganization rather than liquidation, ${ }^{54}$ and as a practical matter, even absent explicit law, insolvent banks often go through some form of reorganization. ${ }^{55}$

well be a better model for bank insolvency law, because banks are supervised by governmental regulators.

${ }^{50}$ See note 41 and accompanying text arguing that, under the existing patchwork framework, any given law governs relatively few insolvencies.

51 This choice should be independent of the local law of the jurisdiction where the branches or agencies are organized. See note 19 and accompanying text. On the other hand, Rasmussen and Thomas (2000) argue that if companies are required to make their choice of bankruptcy venue prior to the time they seek capital in financial markets, managers will have strong incentives to pre-select a forum that will maximize value; Schwarcz (1999) discusses freedom to contract for different bankruptcy procedures.

52 Delaware's motivation to reform and keep its corporate laws updated results from the financial carrot of incorporation fees. Although in the foreign-bank insolvency area, jurisdictions theoretically have some motivation to reform and keep their bank insolvency laws updated in order to attract branches and agencies, as a practical matter those laws are not significant factors in the decision where to organize branches and agencies. See note 19 and accompanying text.

53 See, e.g., Romano (1987) discussing these benefits as resulting from a well-developed Delaware corporation law.

54 See notes 24-25 and accompanying text.

55 E-mail from Peter Swire, Professor of Law, Moritz College of Law, Ohio State University, to the author (Dec. 18, 2004) observing that this can be done through "'hard law' reorganization, such as the U.S. has often done in conservatorship, or 'soft law' reorganization, which the Japanese regulators have done in recent years through forbearance and gradual motion of insolvent banking corporations toward renewed solvency." 
After resolving these issues for the U.S. patchwork framework, it also would be interesting to examine how such issues and their U.S. resolution might inform the "foreign" bank-insolvency regimes of other nations..$^{56}$

I pose these issues and questions as an open research agenda for further study.

\section{References}

American Jurisprudence 2d. St. Paul, MN: West Group.

Baird, Douglas G. 1998. "Bankruptcy's Uncontested Axioms," 108 Yale Law Journal 573.

Baxter, Thomas C., Jr., Joyce Hansen, and Joseph H. Sommer. 2004. "Two Cheers for Territoriality: An Essay on International Bank Insolvency Law," 78 American Banker Law Journal 57.

Bebchuk, Lucian Arye, and Andrew T. Guzman. 1999. "An Economic Analysis of Transnational Bankruptcies," 42 Journal of Law \& Economics 775.

Blackwell, Rob. 2004. "Ruling on Seizure of Failed Foreign Banks' Assets Sticks," American Banker (Aug. 19).

Collier on Bankruptcy, 15th ed. rev. 2004. Alan N. Resnick and Henry J. Sommer, eds. Matthew Bender \& Co.

Degryse, Hans, and Gregory Nguyen. 2004. "Interbank Exposures: An Empirical Examination of Systemic Risk in the Belgian Banking System," Tilburg University Discussion Paper No. 2004-04 (Jan. 2004).

Federal Reserve Board. 2004. "Table 1, Selected Domestic Assets and Liabilities of U.S. Offices of Foreign Banks (December 2004)," available at http://www.federalreserve.gov/releases/iba/Share/SHRTBL1.html.

Financial Centres. 1989. "The Regulation of International Banking," in 11 Financial Centres 5. London: Euromoney Publications Limited.

Malloy, Michael P. 1998. Fundamentals of Banking Regulation. Aspen Law \& Business.

Mattingly, J. Virgil, Ann Misback, Melinda Milenkovich, Joyce M. Hansen, and Joseph H. Sommer. 1999. "United States," in Mario Giovanoli \& Gregor Heinrich, eds. International Bank Insolvencies: A Central Bank Perspective. The Hague, Boston: Kluwer Law International.

Patrikis, Ernest T. 1999. "Role and Functions of Authorities: Supervision, Insolvency Prevention and Liquidation," in Mario Giovanoli \& Gregor Heinrich, eds. International Bank Insolvencies: A Central Bank Perspective. The Hague, Boston: Kluwer Law International.

Rasmussen, Robert K., and Randall S. Thomas. 2000. "Timing Matters: Promoting Forum Shopping by Insolvent Corporations," 94 Nortbwestern University Law Review 1357.

\footnotetext{
${ }^{56}$ It also may be useful to consider the extent to which these issues, and their U.S. resolution, might inform the U.S. legal framework for domestic bank insolvency.
}

Review of Law \& Economics, (C) 2005 by bepress 


\section{U.S. Framework for Foreign-Bank Insolvency / 95}

Risk Institute. 2004. "The Insolvency Liquidation of a Multinational Bank, Summary of Key Legal Concepts," http:/ / riskinstitute.ch/139370.htm (June 10, 2004).

Romano, Roberta. 1987. "The State Competition Debate in Corporate Law," 8 Cardozo Law Review 709.

Samet, Joseph. 2004. "Selected Problems in Multinational Insolvencies," in Emerging Issues in Workouts \& Bankruptcies 2004, What You Need to Know Now! (PLI 2004).

Schwarcz, Steven L. 1995. "A Fundamental Inquiry Into the Statutory Rulemaking Process of Private Legislatures," 29 Georgia Law Review 909.

. 1999. "Rethinking Freedom of Contract: A Bankruptcy Paradigm," 77 Texas Law Review 515.

Scott, Hal S. 1995. "The Competitive Implications of the Basle Capital Accord," 39 St. Louis Law Journal 885.

Shadow Financial Regulatory Committee (AEI). 1999. "International Bank Capital Regulation: A Flawed System in Need of Reform," 1-2. (Sept. 15, 1999). Unpublished manuscript, on file with the University of Pennsylvania Law Review.

Swire, Peter. 1992. "Bank Insolvency Law Now That It Matters Again," 42 Duke Law Journal 469.

Tarbert, Heath Price. 2000. "Are International Capital Adequacy Rules Adequate? The Basle Accord and Beyond," 148 University of Pennsylvania Law Review 1771. 